\title{
Polityka administracji orenburskiej w sprawie islamizacji Stepu Kazachskiego i przyczyny jej zmiany w latach 60 . XIX w. ${ }^{1}$
}

The policy of the Orenburg region administration on the issue of Islamisation of the Kazakh Steppe and the reasons of its change in the 1860s

\section{STRESZCZENIE:}

Imperium Rosyjskie po opanowaniu Stepu Kazachskiego prowadziło politykę administracyjna, której celem był pełny nadzór nad miejscową ludnością. Sposobem na to było wspieranie islamu, co miało ugruntować wpływy rosyjskie poprzez działalność skierowanego tu lojalnego wobec władzy duchowieństwa muzułmańskiego. Pod koniec pierwszej połowy XIX w. nastąpiło jednak osłabienie kontroli nad mułłami. Wobec tego należało zweryfikować pierwotną politykę wobec ludności Stepu. cyjna

Słowa kluczowe: Kazachstan, Imperium Rosyjskie, islamizacja, polityka administra-

Najważniejszą cechą guberni orenburskiej był jej pograniczny charakter w stosunku do stepów kazachskich, a zatem miała ona pełnić kluczową rolę w integracji podbitych Kazachów z ogólnorosyjskim systemem społeczno-politycznym. Rozwiązanie tego zadania nie było możliwe bez uwzględnienia ich przynależności wyznaniowej. Na szczeblu najwyższej władzy państwowej zdecydowano zatem o asymilacji ludności stepu kazachskiego w oparciu o islam.

${ }^{1}$ Referat wygłoszony na IX Światowym Kongresie ICCEES (International Council for Central and East European Studies) w Tokyo (Chiba - Makuhari), w dniach 3-8 sierpnia 2015, sekcja „Kazakh Officials since the 19th century to the 1920s-30s: Position, Rank and Career". 
Wśród współczesnych badaczy historii islamu w społeczeństwie kazachskim pojawiają się wątpliwości co do stopnia zakorzenienia islamu w masowej świadomości Kazachów nawet na początku XX w. Ekstensywna pasterska gospodarka koczownicza Kazachów wymagała nieustannych zmian obozowisk, pozbawiając ich przy tym możliwości posiadania stacjonarnych meczetów i ich regularnego odwiedzania².

Należy oprzeć się na świadectwach podróżników, którzy odwiedzili ziemie kazachskie w połowie XIX w. Zauważyli oni, że:

[...] трудно решить, кто такие киргизы: магометане или язычники, или держатся какой-нибудь своей особенной веры. Все они признают одно высочайшее существо, сотворившее мир, но одни поклоняются ему, как предписывает Коран; другие смешивают учение Магомета с остатками древнего идолопоклонства; третьи думают, что миром управляют два божества: одно - доброе заботится о счастье людей, его называют Худай; другое - здой дух, Шайтан. Кроме этих двух главных богов, они признают многих других духов и добрых и здых, которым приносят жертвы, читают свои модитвы и, протягивая руки кверху, заклинают быть снисходительными‥

Ludy zamieszkujące kazachski step znalazły się także w kręgu zainteresowań ówczesnych etnografów. Jeden z nich, Lew Mejer, tak scharakteryzował tamtejszą społeczność:

[...] киргизы, как известно, магометане и считаются суннитами, но этот народ в настоящее время весьма не развит в религиозном отношении и сам определенно не знает какого религиозного толка он держится. Большая часть киргизов имеет весьма смутное понятие о существовании двух тодков магометанства: суннитского и шиитского. Мало того, самая сущность религии их неизвестна им. Причина тому - кочевой образ жизни и то обстоятельство, что они живут окруженные народами разных исповеданий: христианского, магометанского и языческого ${ }^{4}$.

Tak więc etnografowie tego okresu zdawali sobie sprawę z dwoistej świadomości religijnej Kazachów, łączącej w sobie tradycyjne wierzenia $\mathrm{z}$ islamem.

Z dzisiejszej perspektywy wiemy, że decyzja o integracji Kazachów z Imperium Rosyjskim, opartej na bazie islamu, nie była jedynym wyjściem, ponieważ religię muzułmańską wyznawano w Kazachskich Żu-

${ }^{2}$ А. Франк, Татарские муллы среди казахов и киргизов в XVIII-XIX вв., [w:] Kультура, искусство татарского народа: истоки, традиции, взаилосвязи. Материаль международной конференциии посвященной 70 летию со дня рождения Ф. Х. Валеева, Казань 1993, s. 129.

${ }^{3}$ Очерки зауральской степи Внутренней или Букеевой Орды, Москва 1859, s. 59.

${ }^{4}$ JI. Мейер, Материалы для географии и статистики России, собраннье офицерами генерального штаба. ХІХ. Киргизская степь Оренбургского ведомства, С.-Петербург 1865, s. 228. 
zach $^{5}$ dosyć powierzchownie i nie była ona czymś istotnym dla miejscowej ludności. Jednak najwidoczniej ta informacja nie dotarła do Katarzyny II, która traktowała islamską duchowość Kazachów jako fakt, z którym należy się liczyć w celu uniknięcia poważnych zamieszek i ruchów separatystycznych.

Głównymi propagatorami integracji Kazachów ze społeczeństwem rosyjskim byli muzułmańscy duchowni rosyjskiego Uralu-Powołża, w tym guberni orenburskiej, która w planie administracyjnym obejmowała również Kazachów z Młodszego Żuzu. To miało ułatwić wzajemne relacje zarówno z kazachską arystokracją jak i ze zwykłymi koczownikami. Według trafnej charakterystyki Franza von Schwarza:

[...] русские власти искренне думали, что все центральноазиаты должны быть магометанами и обходились с ними с самого начала как с мусульманами, и, следовательно, обращались с ними как с таковыми. Во всех официальных документах русских властей, направляемых киргиз-кайсакам, Алиах играл большую роль; желая добиться особого расположения киргизов, русское правительство построило им на собственные средства мечети и прислало мулд, чтобы те могли их лучше обучить в духе предполагаемой мусульманской религии 6 .

Na mocy dekretu Katarzyny II z 2 maja 1783 r. w kazachskich żuzach rozpoczęto prężną budowę muzułmańskich kompleksów świątynnych ${ }^{7}$. Budowa meczetów była realizowana nie tylko w stepach, ale i wzdłuż wszystkich linii pogranicznych ${ }^{8}$. Muzułmańskie duchowieństwo zapoznawało Kazachów z islamską dogmatyka, obrzędami i normami religijnymi. Jeszcze pod koniec XVIII w. generał-gubernator guberni orenburskiej Osip Andriejewicz Igelström pisał do Katarzyny II:

Казахи желают, чтоб в Орде в нескольких местах построены были мечети и школы для учения детей. До 40 мулд киргизских приезжали ко мне из Орды просить татарского мулду себе учителем и чтоб я позволил им съездить в Сеитов посад ${ }^{9}$ смотреть тамошний обряд богослужения. Поступившие в Оренбург экземпляры Ко-

${ }^{5}$ Żuz (zwany także w nawiązaniu do tradycji mongolskiej ordą) - ponadplemienna grupa polityczno-ustrojowa u Kazachów, były trzy żuzy: starszy, średni i młodszy [przypis tłum.].

${ }^{6}$ Немецикие исследователи в Казахстане, cz. 1, przekład z j. niemieckiego А. А. Захарова, орrac. И. В. Ерофеева, Алматы 2006, s. 184. 5, k. $1 \mathrm{v}$.

${ }^{7}$ Государственный Архив Оренбургской Области (ГАОО), фонд 5, опис 1, дело

8 Ислам в Российской империи. Законодательные акты, описания, статистика, oprac. Д. Ю. Арапов, Москва 2001, s. 301.

${ }^{9}$ Tatarska wieś w guberni orenburskiej założona przez grupę tatarów kazańskich pod wodzą Seita (Sagita). 
рана казахи с несказанным стремлением разобра-ли. После чего от них поступило

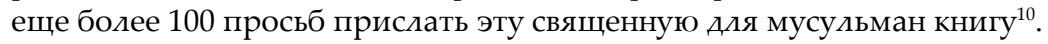

Wymienione przedsięwzięcia władzy państwowej były składową polityki ogólnoimperialnej w tym regionie, której istota znalazła odzwierciedlenie w tytule ukazu z dnia 2 maja $1784 \mathrm{r} .:$ O środkach poskramiania samowoli Kirgiz-Kajsaków ${ }^{11}$. Zasadniczym celem budowy meczetów na stepie kazachskim było zaprowadzenie pokoju w Ordzie. Wznoszenie meczetów było związane z potrzebą wzmocnienia przynależności ziem kazachskich do Imperium Rosyjskiego oraz ucywilizowania miejscowej ludności ${ }^{12}$.

$\mathrm{W}$ imiennym ukazie do gubernatora $\mathrm{O}$. A. Igelströma $\mathrm{z}$ dnia 3 czerwca 1786 r. również zwracano uwagę na konieczność kontynuowania budowy meczetów (a także miast, składów towarowych, szkół), a obok tego nakazywano tworzenie sądu pogranicznego i przeprowadzanie rozpraw wśród Kazachów ${ }^{13}$.

Przedstawiciele kazachskiej arystokracji sami nieraz podejmowali inicjatywę budowy miejsc kultu muzułmańskiego. Władze imperium uwzględniały te dążenia i przekazywały odpowiednie wskazówki władzom lokalnym. Na prośbę jednego z kazachskich sułtanów o budowę meczetu nad rzeką Irtysz, między forpocztami ${ }^{14}$ Semijarskim i Krzywym, car Aleksander I 6 marca 1802 r. nakazał administracji gubernialnej wybrać stosowne miejsce pod inwestycję i opracować kosztorys budowy ${ }^{15}$.

Rząd szczególną uwagę zwrócił na duchowieństwo muzułmańskie. W ukazie z dnia 27 listopada 1785 r. gubernatorowi O. A. Igelströmowi powierzono decyzje dotyczące zatrudniania mułłów w meczetach wznoszonych na Stepie Kazachskim ${ }^{16}$. Gubernator otrzymał polecenie zapewnienia mułłom niemałego wynagrodzenia pieniężnego. Gubernatorowi polecono także nieustannie dbać o potrzeby mułłów. Byli oni zapraszani z guberni kazańskiej i wywodzili się z tamtejszych Tatarów ${ }^{17}$.

Jednym z głównych działań była budowa medras ${ }^{18}$, które otwierano przy meczetach. Utworzenie takich muzułmańskich szkół zostało powie-

\footnotetext{
${ }^{10}$ Российский государственный исторический архив (РГИА), фонд 821, опис 8 , дело 624, к. 26.

${ }^{11}$ РГИА., фонд 821, опис 3, дело 165, k. 11-17.

${ }^{12}$ Ibidem, k. 15.

${ }^{13}$ ГАОО, фонд 6, опис 8, дело 34, k. 17v.

${ }^{14}$ Forpoczta - wysunięty punkt obronny (przypis tłumacza).

${ }^{15}$ ГАОО, фонд 6, опис 8, дело 41, k. 2.

${ }^{16}$ ГАОО, фонд 6, опис 3, дело 320, k. 5-5v.

${ }^{17}$ ГАОО, фонд 6, опис 3, дело 277, k. 13.

${ }^{18}$ Medrasa - teologiczna szkoła muzułmańska, początkowo mieszcząca się przy meczecie, później samodzielna (przypis tłumacza).
} 
rzone gubernatorowi O. A. Igelströmowi zgodnie z ukazem carycy Katarzyny II z 3 czerwca 1786 r. ${ }^{19}$ Koncepcja polityki oświatowej na Stepie Kazachskim była przedstawiona w reskrypcie Katarzyny II z 12 listopada 1786 r. i składała się z takich elementów, jak: zabezpieczenie kadrowe systemu oświaty, struktura, zakres nauczania itd. ${ }^{20}$ Następnym krokiem rządu była próba wprowadzenia w Młodszej Ordzie specjalnych norm sprowadzających się do sekularyzacji edukacji. Jednakże te plany nie mogły dojść do skutku, ponieważ ich realizacja była powierzona duchowieństwu muzułmańskiemu. Polityka zatrudniania w szkołach mułłów spotkała się z krytyką orenburskiej administracji gubernialnej. Gubernatorowi Michaiłowi Wołkońskiemu mułłowie pochodzenia tatarskiego wydawali się niewystarczająco godni zaufania: obawiano się rozpalenia przez nich wśród Kazachów religijnego fanatyzmu ${ }^{21}$. W istocie rząd rosyjski pod koniec XVIII w. i w pierwszej połowie XIX w. bezpośrednio przyczynił się do tego, że Kazachowie islamizowali się w coraz większym stopniu.

Należy podkreślić raz jeszcze, że muzułmańskie duchowieństwo było uznawane za urzędników państwowych. W trakcie omawianego procesu, realizowanego zarówno na terenie kraju orenburskiego, jak i na południe od jego granic (na ziemiach Średniego i Starego Żuzu, niepodlegających kontroli Orenburga), miejscowe muzułmańskie elity religijne miały przejawiać aktywność nad zabezpieczeniem bytu rodów kazachskich wiernych władzom rosyjskim. W roku 1790 pierwszy mufti ${ }^{22}$ Orenburskiego Muzułmańskiego Związku Religijnego Muchamedżan Chusainowan Chusajnow sporządził listę mułłów regionu Wołgo-Uralskiego, których w zależności od ich prawomyślności rekomendował albo nie rekomendował do decydowania w sprawach kirgiz-kajsackich ${ }^{23}$.

Należy zwrócić uwagę na listę duchownych, którzy nie byli rekomendowani do udziału w „kazachskich sprawach”, ponieważ mufti uważał ich za ludzi niepewnych: „они получили образование в Константинополе, Индии и Бухаре, возомнили себя шейхами, не понимали и искажали смысл Алкорана и правил магометанского закона, имеди сношения с шейхом Фаизханом, вели с ним переписку, отправляли к нему своих учеников. Они будут подбивать непросвещенных киргиз-кайсаков к отказу от верноподданства под российским скипетром".

\footnotetext{
${ }^{19}$ ГАОО, фонд 6, опис 3, дело 279, k. 2.

${ }^{20}$ Полное Собрание Законов Российской Империи (ПСЗРИ), собрание 1-е, t. 22, 1786, nr16400.

${ }^{21}$ ГАОО, фонд 6, опис 1, дело 87, k. 3-7.

${ }^{22} \mathrm{Mufti}$ - muzułmański prawnik i teolog wydający oficjalne interpretacje w sprawach życia państwowego i prywatnego, związanego z islamem (przypis tłumacza).

${ }^{23}$ ГАОО, фонд 6, опис 2, дело 114, k. 42-67.
} 
Wśród takich mułłów znalazło się siedmiu pełniących służbę w guberni orenburskiej ${ }^{24}$.

Owa prawomyślność była niezwykle ważna, ponieważ mułłowie $\mathrm{w}$ założeniach władz mieli być rosyjskimi agentami politycznymi i popierać interesy państwowe $\mathrm{w}$ stepach. Właśnie taką rolę muzułmańskie duchowieństwo odegrało na przykład w 1790 r., kiedy przed obraniem Ajczuwaka na chana Mniejszej Ordy generał-gubernator namiestnictwa ufimskiego i symbirskiego baron O. A. Igelström skierował do Ordy muftiego M. Chusainowa z listami do rady chanatu, polecającymi, żeby rody kazachskie zebrały się $\mathrm{w}$ górnym odcinku rzeki Kobdy i przystąpiły do rozpatrywania spraw ordyńskich i wyboru chana ${ }^{25}$.

Mając możliwość swobodnego przemieszczania się po kazachskich obozach celem odprawiania obrzędów religijnych, mułłowie często spełniali funkcje rządowych wysłanników. Wiadomo na przykład, że muftiemu M. Chusainowi podczas podróży do Średniej Ordy w 1790 r. towarzyszyli mułłowie guberni orenburskiej Birkaitimow, Busmanbiłłow, Chisamttdanow, którzy niejednokrotnie bywali w Ordzie ${ }^{26}$. Według polecenia O. A. Igelströma mieli oni co tydzień, a jeśli należało, to i częściej, referować, co się działo w Ordzie. Od nich generał-gubernator na bieżąco otrzymywał informacje o nastrojach, zatargach między rodami i grupami społeczności kazachskiej. Właśnie na podstawie takich doniesień Igelström uznał, że większość Kazachów Średniej Ordy będzie wolała wybrać na chana starszego syna zmarłego Nurali Chana - Pargaliego. Przedstawiciele rodu semiradzkiego pragnęli natomiast, żeby wybrano starego i chorego sułtana Ajczuwaka. Część Kazachów była za wyborem Srym Datowa jako jednego z potomków Kaib Chana. Owa starszyzna nie cieszyła się jednak autorytetem wśród Kazachów ${ }^{27}$.

Należy podkreślić, że funkcja muzułmańskiego duchowieństwa w tej złożonej sytuacji politycznej nie ograniczała się do wywiadu i informowania władz orenburskich o sytuacji w Ordzie. Przysłani z Orenburga mułłowie byli też instrumentem wpływu w konkretnych sytuacjach. Generał-gubernator dał muftiemu, który przewodniczył delegacji, następujące wskazówki:

Bo-1, во всех отношениях с султанами, членами совета, биями, батырами и лучшими людьми из казахов, склонять их к соблюдению мира и тишины в Орде, стойко и беспрестрастно разбирать все происходящие между ними неудовольствия, никог-

\footnotetext{
${ }^{24}$ Ibidem, k. 44-46.

${ }^{25}$ ГАОО, фонд 6, опис 2, дело 115, k. 3-5.

${ }^{26}$ ГАОО, фонд 6, опис 2, дело 99, k. 1-16.

${ }^{27}$ Ibidem, k. 89-107v.
} 
да при этом не показывая никакой над ними власти, а только показывать себя как знаменитейшую духовную особу, к тому же доброжелательно к ним настроенную; во-2, обо всем, в Орде про-исходящем, еженедельно доносить генерал-губернатору, а если обстоятель-ства дела того потребуют, то и чаще; в-3, стараться внушать лучшим в Орде людям не допускать, чтобы какими-либо воровскими шайками учинены были хищнические набеги на границы, доказывая им, что такие дерзости без строгого наказания остаться не могут; в-4, не допускать до того, чтобы собирались в Орде скопища, сборища, осведомлять о подобных сборищах и их зачинщиках; в-5, наблюдать и через надежных людей разведывать о том, имеет ли киргиз-кайсацкий народ вообще желание, чтобы им позволено было выбрать себе нового хана и, не способствуя усилению какой-либо „партии”, ожидать дальнейших распоряжений со стороны генерал-губернатора ${ }^{28}$.

Misja dyplomatyczna powierzona grupie duchowieństwa muzułmańskiego, znającego kulturę duchową Kazachów, została przeprowadzona skutecznie. W Ordzie Mniejszej zebrała się rada chańska, na której Kazachowie na Koran złożyli Rosji przysięgę i odprawili modlitwę według obrządku muzułmańskiego o zdrowie Jego Imperatorskiej Wysokości, chanem zaś wybrali Ajczuwaka - „престарелого и здоровьем слабого, но благомысленного, миролюбиво к России настроенного" 29.

W XVIII w. i pierwszej połowie XIX w. Orenburski Zarząd Gubernialny systematycznie zaspokajał zapotrzebowanie kazachskich mieszkańców guberni orenburskiej na mułłów. $Z$ dokumentów kancelarii generał-gubernatora można się dowiedzieć, że do 1851 r. na terenie Młodszego Żuzu działało ok. 17-20 mułłów w każdym rejonie ${ }^{30}$.

$\mathrm{Na}$ wykresie przedstawiono liczebność muzułmańskich mułłów w Młodszym Żuzie, wykazaną w sprawozdaniu Departamentu Spraw Duchownych Obcych Wyznań Ministerstwa Spraw Wewnętrznych, przedstawionym na posiedzeniu Komitetu Ministrów, który obradował $\mathrm{w}$ sprawach muzułmańskich $\mathrm{w}$ związku z planami wydzielenia z guberni orenburskiej samodzielnego obwodu turgajskiego (co nastąpiło w 1867 r. $)^{31}$. Z wykresu wynika, że nasycenie mułłami Stepu Kazachskiego stale wzrastało. Jeśli w pierwszych latach po ukazach Katarzyny II było ich tylko 19, to do 1803 r., kiedy już istniało Wojenne Gubernatorstwo Orenburskie, ich liczebność zwiększyła się ponadpięciokrotnie. W 1825 r., $\mathrm{w}$ związku z wprowadzeniem Устава оренбургских киргиз i przebudowa administracyjną terytorium Młodszego Żuzu, znów przeprowadzono spis mułłów, których w porównaniu z 1803 r. przybyło o 44\%. Nowego spisu dokonano w 1833 r. w związku z wprowadzeniem dwa lata wcześniej sys-

\footnotetext{
${ }^{28}$ ГАОО, фонд 6, опис 1, дело 100, k. 50-51.

${ }^{29}$ Ibidem, k. 53.

${ }^{30}$ ГАОО, фонд 6, опис 10, дело 14005, k. 45.

${ }^{31}$ РГИА, фонд 821, опис 1, дело 1002, k. 1-24.
} 


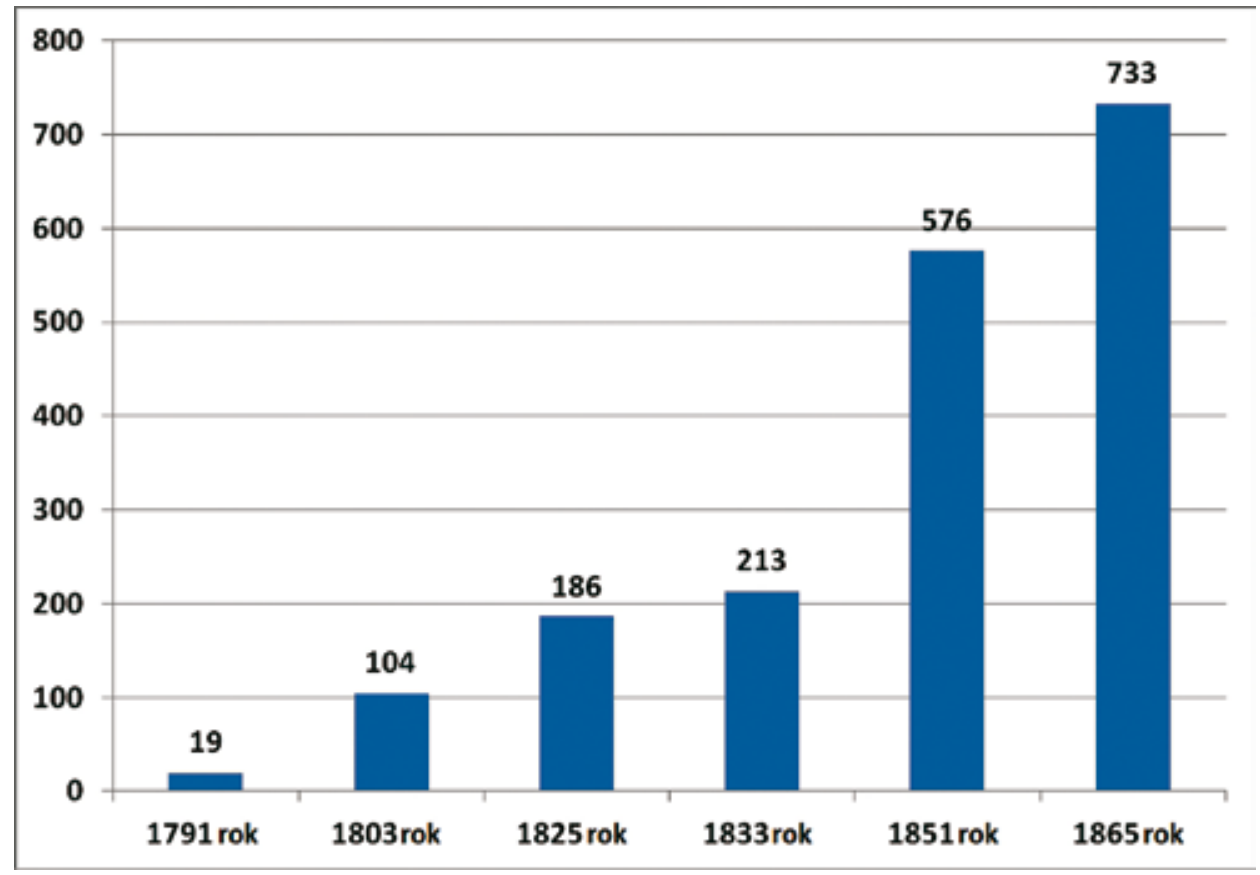

Ryc. 1. Liczebność muzułmańskich mułłów oddelegowanych do Młodszego Żuzu

temu administracyjnego dystancji (rejonów) wśród Kirgizów. Wykazał on wzrost liczby mułłów jeszcze o $12 \%$, szybszy niż w ciągu dziesięciolecia! W warunkach podziału administracyjnego na dystancje do $1851 \mathrm{r}$. liczba, mułłów przekroczyła 500 osób, zatem wzrost od poziomu z 1833 r. wyniósł 2,7 raza. Do momentu wydzielenia obwodu turgajskiego z guberni orenburskiej liczba mułłów na terenie Młodszego Żuzu wzrosła jeszcze o 21\%, tj. do liczby 733 muzułmańskich duchownych. W ten sposób w ciągu 75 lat (1791-1865) liczba mułłów na Stepie Kazachskim wzrosła 39-krotnie, co niewątpliwie świadczyło o islamizacji tego terytorium w jego części podporządkowanej władzom administracyjnym w Orenburgu.

Powyższe dane zasadniczo różnią się od wniosku Biganszy Bierkimbajewny Alimbajewy, która w ostatnim paragrafie swojej dysertacji zwróciła szczególną uwagę na ten problem. Doszła do konkluzji, że istota polityki wyznaniowej w odniesieniu do ziem kazachskich sprowadzała się do tego, że „muzułmanom nie przeszkadzano w budowie meczetów, tworzeniu szkół" ${ }^{\prime 2}$. Gubernialna administracja orenburska nie tylko nie

${ }^{32}$ Б. Б. Алимбаева, Политика российского правительства в отношении оренбургских казахов в XVIII-XIX вв., Москва 2008, s. 25, maszynopis pracy kandydackiej. 
wysyłała na kontrolowany przez nią step prawosławnych misjonarzy, ale wręcz przeciwnie, na pierwsze życzenie wyjawione ze strony plemion kazachskich kierowano do nich muzułmańskiego mułłę. Ta sytuacja w pełni odpowiadała hasłu polityki islamizacji stepu.

Oczywiście mułłowie mieli za zadanie nie tylko zaszczepiać Kazachom normy szarjatu, ale co ważniejsze dla władz imperium - byli oni zobowiązani kształtować przestrzegających rosyjskie prawo, lojalnych wobec władzy członków społeczeństwa. Duchowieństwo miało obowiązek przekonywania „prostych i nieświadomych Kirgizów” do zaniechania przemocy, poszanowania i pokory wobec rosyjskiej monarchii i swoich władz ${ }^{33}$.

Jednakże z upływem czasu stało się jasne, że przyjęta pod koniec XVIII w. decyzja o stopniowej islamizacji Stepu Kazachskiego miała nie tylko pozytywne (w aspekcie osiągnięcia pewnej stabilności społecznej, lojalności wobec państwa rosyjskiego), ale i negatywne (z punktu widzenia władzy) następstwa. Bowiem w wyniku tego procesu stworzone na stepie islamskie społeczeństwo na pewnym etapie swojego rozwoju zaczynało chętniej podążać w kierunku tataryzacji niż rusyfikacji. Szczególnie widać to na przykładzie ewolucji społeczeństwa kazachskiego w Bukiejewskiej (Wewnętrznej) Ordzie. Na podstawie obserwacji Anny Jewreinowej zwiększenie liczebności mułłów w Bukiejewskiej Ordzie, oprócz moralnego wpływu na naród w sensie religijnym, sprzyjało temu, że życie sułtanów i zamożnych osób pod wieloma względami zaczynało przypominać życie Tatarów ${ }^{34}$. Znany rosyjski etnograf Aleksiej Nikołajewicz Charuzin zauważył, że:

[...] букеевский киргиз пришел к нам 90 лет тому назад: ... мы помним, каким он пришел и каким стал теперь. Он пришел, вооруженный копьем и айбалтой, перекочевывая с места на место и живя в кибитке; теперь он, до некоторой степени, оседлый, живет зимою в глиняном доме, бросил оружие; пришел язычником, теперь он магометанин; жил прежде, строго соблюдая свои родовые и сословные традиции, теперь он их забыл; жил большими семьями, а теперь нет... Татарин для киргиза авторитет; цивилизующийся киргиз сбрасывает свой киргизский (бухарский) халат и надевает татарский; цивилизованный киргиз, надев чистый халат идет вместе с татарином на вечернюю модитву в мечеть, и высшая мечта киргиза не обрусеть, а отатариться. ${ }^{35}$

${ }_{33}$ РГИА, фонд 821, опис 1, дело 1011, k. 13-13v.

${ }^{34}$ А. Евреинов, Внутренняя или Букеевская киргиз-кайсацкая орда, Оренбург 1851, s. 73.

${ }^{35}$ А. Н. Харузин, Степные очерки (Киргизская Букеевская орда). Странички из записной книжки, Москва 1888, s. 96, 155. 
Taka sytuacja nie mogła zadowalać władz imperium. W latach 60 . XIX w. rozpoczął się proces ograniczania wpływu religii muzułmańskiej na stepie ${ }^{36}$. Временное положение z 21 października 1868 r. było krokiem $\mathrm{ku}$ osłabieniu wpływu islamu na Kazachów. Duchowe sprawy Kazachów zostały wykreślone z kompetencji Orenburskiego Muzułmańskiego Związku Religijnego i przekazane orenburskim władzom administracyjnym $^{37}$. Zezwolono na działanie jednego meczetu z jednym mułłą na włość, wyznaczonym wyłącznie spośród Kazachów oraz powołanym i odwoływanym przez gubernatora wojennego ${ }^{38}$. Następstwem realizacji tej ustawy było to, że np. w obwodzie turgajskim Kazachowie mieli nie więcej niż 15 meczetów na 50 włości, czyli na jeden meczet przypadało 5-10 tysięcy dusz płci męskiej ${ }^{39}$. Jednakże $w$ warunkach stepowych trudno było zapobiec samowolnej budowie domów modlitwy. Takie przypadki, stale powtarzające się, świadczyły o tym, że oficjalnie istniejące meczety nie zaspokajały już religijnych potrzeb ludności. Zamykanie nielegalnych domów modlitwy i odmowa ich budowy wprowadzały „в умы добродушных и преданных правительству кочевников подозрительность и предположение о запрете совершать богослужение" ${ }^{\prime 0}$. Podejrzliwość ta szczególnie uwidoczniła się na stepie podczas pierwszego spisu powszechnego w 1897 r., kiedy niewypełniona została rubryka formularza dotycząca religii ${ }^{41}$. Osłabić pozycję islamu na Stepie Kazachskim w drugiej połowie XIX w. było już jednak bardzo trudno. O skutecznej islamizacji Kazachów świadczy również fakt słabego przyjmowania się wśród nich chrześcijaństwa. Nieśmiałe próby chrystianizacji kończyły się niepowodzeniem. Przez 10 lat, od 1853 do 1862 r., na Stepie Kirgiskim pod zarządem orenburskim ochrzczono w sumie 127 osób, przy сzуm „Аюди эти были преступники, искавшие спасения в отступничестве, и вообще народ порочный, по каким-дибо причинам отринутый своими соотечественниками" ${ }^{42}$.

Podsumowując, cechą guberni orenburskiej było to, że na jej terenie aż do $1860 \mathrm{r}$. wraz z polityką chrystianizacji prowadzono politykę islamiza-

${ }^{36}$ S. Lyubichankovskiy, Local Administration in the Reform Era and After: Mechanisms of Au-thority and their Efficacy in Russia, "Kritika: Explorations in Russian and Eurasian History" 2012, Vol.13, nr 4, s. 861-875; Местное управление в пореформенной России: механизми власти и их эффективность: сводные материаль заочной дискуссии, ЕкатеринбургИжевск 2010.

${ }^{37}$ ГАОО, фонд 6, опис 12, дело 1486, к. 76.

${ }^{38}$ Ibidem.

${ }^{39}$ ГАОО, фонд 10, опис 5, дело 601, k. 12.

${ }^{40}$ Ibidem, k. 87-89.

${ }^{41}$ ГАОО, фонд 11, опис 11, дело 304, k. 13, 24-25, 47v.

${ }^{42}$ JI. Мейер, op.cit., s. 229. 
cji odnośnie do Kazachów stanowiących w różnym czasie od 12\% mieszkańców regionu orenburskiego w 1796 r. do 24\% mieszkańców guberni orenburskiej w 1897 r. Polityka systematycznego wspierania islamu na określonym terytorium guberni i poza jej granicami, poprzez wspieranie i finansowanie działalności misyjnej duchowieństwa muzułmańskiego, była obiektywną przeszkodą $\mathrm{w}$ chrystianizacji na pozostałym terytorium guberni, ponieważ, po pierwsze, podważono ideologiczny fundament chrystianizacji; po drugie, został wyszkolony w charakterze misjonarzy i agitatorów cały szereg wybitnych muzułmańskich duchownych, wykorzystujących swoje znajomości i umiejętności nie tylko na terenie stepów kazachskich; po trzecie, członkowie religijnych elit muzułmańskich doskonale orientowali się $\mathrm{w}$ procesie podejmowania i wprowadzania w życie decyzji na terenie guberni orenburskiej, co dawało im dodatkowe możliwości subtelnej i elastycznej obrony swoich interesów religijnych.

(Tłum. z języka rosyjskiego Izabela Magala)

\section{BIBLIOGRAFIA:}

Алимбаева Б. Б., Политика российского правительства в отношении оренбургских казахов в XVIII-XIX вв., Москва 2008.

Евреинов А., Внутренняя или Букеевская киргиз-кайсацкая орда, Оренбург 1851.

Ислам в Российской империи. Законодательные акты, описания, статистика, орrас. Д. Ю. Арапов, Москва 2001.

Lyubichankovskiy S., Local Administration in the Reform Era and After: Mechanisms of Authority and their Efficacy in Russia, „Kritika: Explorations in Russian and Eurasian History" 2012, Vol.13, nr 4, s. 861-875.

Местное управление в пореформенной России: механизмы власти и их эффективность: сводные материалы заочной дискуссии, Екатеринбург-Ижевск 2010.

Немецикие исследователи в Казахстане, cz. 1, przekład z j. niemieckiego 1 . А. Захарова, орrac. И. В. Ерофеева, Алматы 2006.

Очерки зауральской степи Внутренней или Букеевой Орды, Москва 1859.

Франк А., Татарские мулль среди казахов и киргизов в XVIII-XIX вв., [w:] Культура, искусство татарского народа: истоки, традиции, взаимосвязи. Материаль международной конференции посвященной 70 летию со дня рождения Ф. Х. Валеева, Казань 1993.

Харузин А. Н., Степнье очерки (Киргизская Букеевская орда). Странички из записной книжки, Москва 1888.

\section{ABSTRACT:}

After capturing the Kazakh Steppe the administrative policy of the Russian Empire aimed at putting the inhabitants of the Steppe under control. The governmental administration decided to support Islam in this territory since this religion was supposed to strengthen the Russian influence by controlling the local people through activities of the 
Muslim clergy. At the end of the first half of the 19th century the control over local mullahs and the people they had contact with weakened. Due to this the Russian administrative policy towards the inhabitants of the Kazakh Steppe had to be verified.

Key words: Kazakhstan, Russian Empire, islamisation, administrative policy

\section{NOTA O AUTORZE:}

Siergiej W. Lubiczankowski - doktor nauk historycznych, profesor, kierownik Katedry Historii Rosji Orenburskiego Państwowego Uniwersytetu Pedagogicznego. Jest czołowym naukowym współpracownikiem Powołżańskiej Filii Instytutu Historii Rosji Rosyjskiej Akademii Nauk, e-mail: svlubich@yandex.ru. 